\title{
Conjunctival Melanoma pM1 TNM Finding v8
}

National Cancer Institute

\section{Source}

National Cancer Institute. Conjunctival Melanoma pM1 TNM Finding v8. NCI Thesaurus.

Code C140582.

Conjunctival melanoma with distant metastasis. (from AJCC 8th Ed.) 